Short Communication

\title{
A comparative study of protein patterns of human estrogen receptor positive (MCF-7) and negative (MDA-MB-231) breast cancer cell lines
}

\author{
Dana Flodrova $^{1}$, Lucia Toporova ${ }^{2}$, Dana Macejova $^{2}$, Marketa Lastovickova $^{1}$, Julius Brtko ${ }^{2}$ \\ and Janette Bobalova ${ }^{1}$ \\ ${ }^{1}$ Institute of Analytical Chemistry of the CAS, v. v. i., Veverí 97, 60200 Brno, Czech Republic \\ ${ }^{2}$ Institute of Experimental Endocrinology, BMC, Slovak Academy of Sciences, Dúbravská cesta 9, 84505 Bratislava, Slovak \\ Republic
}

\begin{abstract}
In the present study, we analyzed the cell lysates of human tumour cell lines representing two major clinically different types of breast cancer. Our main goal was to show the differences between them on proteomic level. Gel electrophoresis followed by MALDI-TOF MS analysis was used for proteins determination. Exactly 98 proteins were unequivocally identified and 60 of them were expressed differentially between MDA-MB-231 and MCF-7 cell lines. Among the proteins reported here, some well-known breast cancer markers (e.g., annexin A1, annexin A2 and vimentin) were identified in the MDA-MB-231 cell line and thus we were able to distinguish both cell lines sufficiently.
\end{abstract}

Key words: Cell line - Breast cancer - Mass spectrometry — Proteins

In the present cancer research, tumour cell lines have wide utilization as in vitro models that provide essential tools in many aspects of laboratory research. Their using offers a lot of advantages, e.g., unlimited self-replication source of sample, easy handling, and relatively high degree of homogeneity (Khan 2013; Bialesova et al. 2015). Nevertheless, the utilization of cell lines has also some drawbacks because they do not represent the current diversity and heterogeneity of tumour, and moreover their genotype and phenotype can drift during their continual culture (Mladkova et al. 2010).

Generally, breast cancers are assorted into 3 clinical types based on the presence or absence of three biomarkers: (1) human epidermal growth factor receptor 2 (HER2)-positive, (2) estrogen receptor (ER) and/or progesterone (PR)-positive/ HER2-negative and (3) triple-negative (Whelan et al. 2012). MCF-7, established at the Michigan Cancer Foundation in 1973 (Soule et al. 1976), and MDA-MB-231 established in 1974 (Cailleau et al. 1974) are the most commonly used breast cancer cell lines in the world. Both lines originated from pleural effusions of metastatic mammary carcinoma

Correspondence to: Janette Bobalova, Institute of Analytical Chemistry of the CAS, v. v. i., Veveří 97, 60200 Brno, Czech Republic E-mail: bobalova@iach.cz patients (Mladkova et al. 2010). MCF-7 cells were isolated from 69 year old woman with metastatic disease (Keen 2010) and they represent an ideal model for studies of hormone response because they have high hormone sensitivity through expression of ER (Levenson and Jordan 1997). This cell line expresses markers of the luminal epithelial phenotype of breast cells, the MDA-MB-231 line does not express them but it contains a high level of vimentin, a marker of the mesenchymal phenotype. MDA-MB-231 is also used as a model for triple negative breast cancers (Mladkova et al. 2010). These two cell lines are used in the present study in an attempt to compare their protein patterns by using the combination of two methodological approaches, SDS-PAGE and mass spectrometry (MS).

The cancer cell cultures were purchased from the HPACC (Salisbury, Great Britain). Cells were grown and passaged routinely as monolayer cultures. For experiments, the cells were used at passage 10-30. Cells were seeded in Petri dishes in Dulbecco's modified Eagle's medium (DMEM) supplemented with $10 \%$ fetal bovine serum (FBS), antibiotics (penicillin, streptomycin, gentamicin) and cultured in humidified atmosphere of $5 \% \mathrm{CO}_{2}$ and $95 \%$ air at $37^{\circ} \mathrm{C}$. After incubation, the cells were washed with ice-cooled PBS. The cell lysis was made according to manual instruction from the 
RIPA buffer by Sigma. The cell lysates were stored at $-70^{\circ} \mathrm{C}$ for further use. Before gel electrophoresis, samples were dialyzed against deionized water using Slide-A-Lyzer dialysis cassettes (Thermo Fisher Scientific, Waltham, MA, USA) with $2 \mathrm{kDa}$ cut-off and lyophilized. Purified samples were dissolved in $300 \mu$ l of the Laemmli sample buffer. After briefly being boiled $\left(10 \mathrm{~min}, 95^{\circ} \mathrm{C}\right)$ in a water bath, samples were applied onto the $12 \%$ SDS gel. Separations were performed at constant voltage $140 \mathrm{~V}$. The visualization was carried out using Coomassie Brilliant Blue G-250 dye. Stained protein spots were excised from the gel and digested (after reduction with $10 \mathrm{mM}$ dithiothreitol and subsequent alkylation with $55 \mathrm{mM}$ iodoacetamide) with trypsin (digestion buffer: $50 \mathrm{mM} \mathrm{NH}_{4} \mathrm{HCO}_{3}, 5 \mathrm{mM} \mathrm{CaCl}_{2}, 12.5 \mathrm{ng} / \mu \mathrm{l}$ of enzyme) overnight at $37^{\circ} \mathrm{C}$. The resulting tryptic peptides were extracted from the gel by $0.1 \%$ trifluoroacetic acid (TFA) and acetonitrile $(1: 1, \mathrm{v} / \mathrm{v})$. For mass spectrometric analyses, the extracts were purified by ZipTip $\mathrm{C}_{18}$ (Millipore).

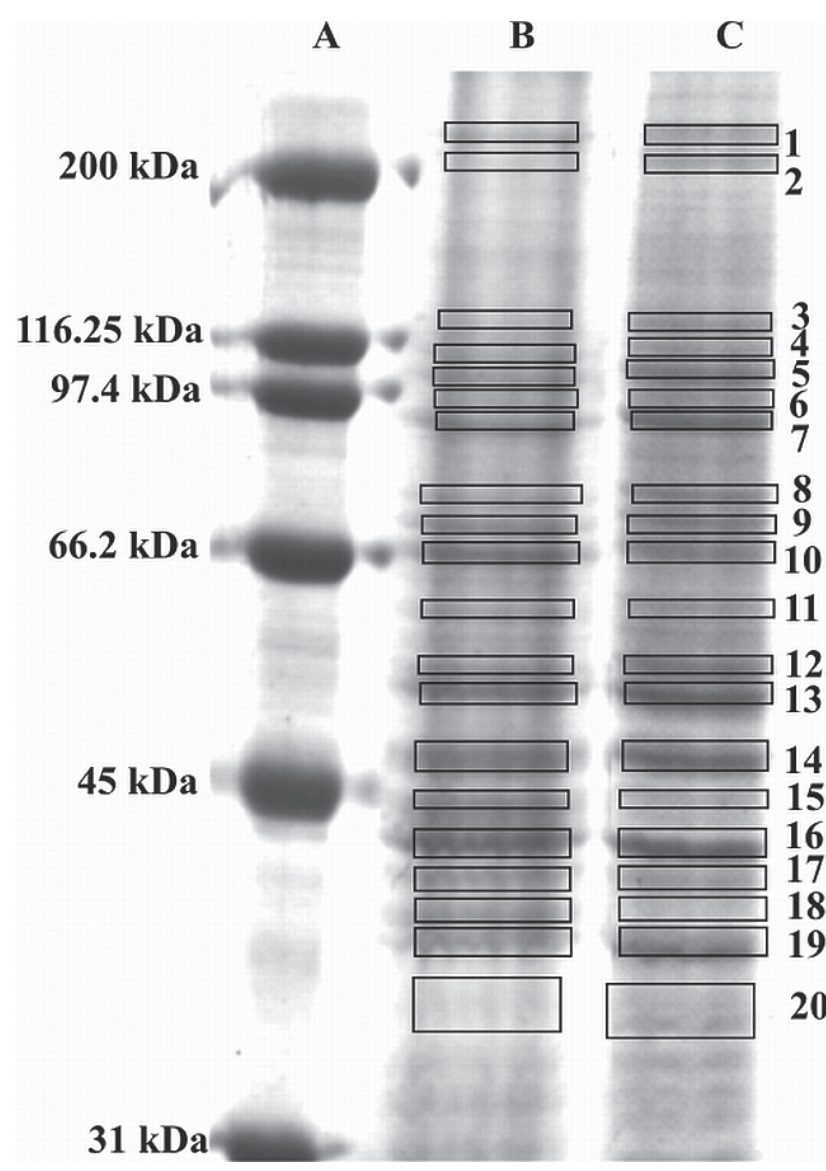

Figure 1. SDS-PAGE separation of cell lysis (molecular weight markers, A) from individual human breast cancer cell lines: MCF-7 $\mathrm{ER}^{+}$cell line (B) and MDA-MB-231 ER cell line (C). The rectangles mark excised and MS analyzed proteins bands which were successfully identified.
A solution of $\alpha$-cyano-4-hydroxycinnamic acid $(8 \mathrm{mg} / \mathrm{ml}$ in acetonitrile/0.1\% TFA, 1:1, v/v) was used for both MS and MS/MS analysis of peptides. MALDI MS experiments in positive ion reflectron mode were performed on $A B$ SCIEX TOF/TOF 5800 System (AB SCIEX, Framingham, MA, USA) equipped with a $1 \mathrm{kHz}$ Nd:YAG laser. Acquired mass spectra were processed using 4000 Series Explorer software and the data were submitted to the Mascot database searching. Protein identifications were assigned using the NCBInr database with taxonomy restriction to Homo sapiens. Maximum tolerance for peptide masses as well as fragment error was set to $0.3 \mathrm{Da}$. Additional parameters used: enzyme trypsin; allowed missed cleavages: up to one, fixed modification: carbamidomethyl, no variable modification; peptide charge: +1 ; monoisotopic masses; instrument MALDI-TOF/TOF.

In this work, we compared protein patterns between MCF-7 cell line and MDA-MB-231 cell line by simply comparative proteomics based on combination of $1 \mathrm{D}-\mathrm{GE}$ and tandem MS. Comparative proteomics offers a dynamic view on the proteome including the qualitative and quantitative changes of proteins (Farinha et al. 2011). Our study had two aims: a) to perform a basic comparison of breast cell lines based on SDS-gels protein profiles; and b) to identify the major proteins of both cell lines. Fig. 1 shows protein profiles of the studied cell lines. A visual inspection of protein patterns indicated that MCF-7 cell line shares a lot of similarities with the line MDA-MB-231. Significant differences in the electrophoretic profiles of both cell lines were observed at molecular masses of about 35, 44, 53, 100-120 and 210 $\mathrm{kDa}$. Different as well as mutual strongest protein bands on the gels, marked in Fig. 1, were excised, in-gel digested with trypsin and gained peptide mixtures, originated from individual gel bands, were analyzed by MALDI-TOF MS. Additional MS/MS analysis of individual peptides and following database searching resulted in identification of the proteins summarized in Table 1.

MALDI-TOF MS analysis revealed 98 proteins across MCF-7 and MDA-MB-231 (Table 1). Out of which 60 were mutually differently expressed for MDA-MB-231 and MCF-7.

Identified proteins can be divided into several main groups: (1) actins; (2) actinins; (3) tubulins; (4) heat shock proteins; (5) annexins; (6) keratins and (7) others.

Actins (band 1, 16, 17), actinins (band 5, 6) and tubulins (band 13) represent major proteins observed in both studied cell lines. The most numerous group of heat shock proteins at complete scale of molecular weights is included in both cell lines (bands $4,8,9,11$ ). These proteins interact dynamically with various co-chaperones that modulate their substrate recognition, ATPase cycle and chaperone function. Furthermore, heat shock proteins, in general, are also involved in mode of steroid hormones action through 
Table 1. Summary of identified proteins obtained by MS measurement

\begin{tabular}{|c|c|c|c|c|c|}
\hline Band & MCF-7 & $\begin{array}{l}\text { MDA- } \\
\text { MB-231 }\end{array}$ & Protein & $\begin{array}{l}\text { NCBInr } \\
\text { number }\end{array}$ & $\begin{array}{l}\text { Molecular } \\
\text { mass }(\mathrm{Da})\end{array}$ \\
\hline \multirow[t]{2}{*}{1} & $\mathrm{Y}$ & $\mathrm{Y}$ & filamin A & gi|53791219 & 277332 \\
\hline & $\mathrm{Y}$ & $\mathrm{Y}$ & actin-binding protein homolog ABP-278 & gi|3282771 & 278018 \\
\hline \multirow[t]{3}{*}{2} & $\mathrm{Y}$ & - & fatty acid synthase & gi|915392 & 272919 \\
\hline & - & $\mathrm{Y}$ & myosin-9 & gi|12667788 & 226392 \\
\hline & - & $\mathrm{Y}$ & talin & gi $\mid 6682361$ & 269550 \\
\hline \multirow[t]{2}{*}{3} & $\mathrm{Y}$ & $\mathrm{Y}$ & heterogeneous nuclear ribonucleoprotein $\mathrm{U}$ isoform $\mathrm{b}$ & gi|14141161 & 88924 \\
\hline & - & $\mathrm{Y}$ & karyopherin beta 3 & gi|2102696 & 123512 \\
\hline \multirow[t]{6}{*}{4} & $\mathrm{Y}$ & $\mathrm{Y}$ & nucleolin & gi|189306 & 76298 \\
\hline & $\mathrm{Y}$ & $\mathrm{Y}$ & ubiquitin activating enzyme E1 & gi|35830 & 117715 \\
\hline & Y & - & nuclear corepressor KAP-1 & gi|1699027 & 88479 \\
\hline & - & $\mathrm{Y}$ & $100 \mathrm{kDa}$ coactivator & gi|799177 & 99628 \\
\hline & - & $\mathrm{Y}$ & heat shock protein 70 & gi| 292160 & 78945 \\
\hline & - & $\mathrm{Y}$ & exportin-1 & gi| 4507943 & 123306 \\
\hline \multirow[t]{9}{*}{5} & $\mathrm{Y}$ & $\mathrm{Y}$ & alpha actinin 4 & gi|2804273 & 102204 \\
\hline & $\mathrm{Y}$ & $\mathrm{Y}$ & endoplasmin precursor & gi|4507677 & 92411 \\
\hline & $\mathrm{Y}$ & $\mathrm{Y}$ & glucosidase II & gi|2274968 & 106833 \\
\hline & $\mathrm{Y}$ & $\mathrm{Y}$ & splicing factor, proline- and glutamine-rich & gi| 4826998 & 76102 \\
\hline & $\mathrm{Y}$ & - & keratin 1 & gi|7331218 & 65978 \\
\hline & - & $\mathrm{Y}$ & alpha-actinin-1 isoform b & gi|4501891 & 102993 \\
\hline & - & $\mathrm{Y}$ & unnamed protein product $(=$ alpha actinin 1$)$ & gi|28334 & 103480 \\
\hline & - & $\mathrm{Y}$ & chain A, the crystal structure of human muscle alpha-actinin & gi|731187793 & 101834 \\
\hline & - & $\mathrm{Y}$ & KIAA0088 (= alpha glucosidase) & gi|577295 & 107158 \\
\hline \multirow[t]{3}{*}{6} & Y & $\mathrm{Y}$ & elongation factor 2 & gi| 4503483 & 95277 \\
\hline & $\mathrm{Y}$ & $\mathrm{Y}$ & transitional endoplasmic reticulum ATPase & gi $\mid 6005942$ & 89266 \\
\hline & - & $\mathrm{Y}$ & alpha-actinin & gi $\mid 178058$ & 103229 \\
\hline \multirow[t]{7}{*}{7} & $\mathrm{Y}$ & $\mathrm{Y}$ & heat shock protein HSP 90-beta isoform a & gi|20149594 & 83212 \\
\hline & Y & $\mathrm{Y}$ & HSP90AA1 protein & gi|83318444 & 68329 \\
\hline & $\mathrm{Y}$ & $\mathrm{Y}$ & calnexin precursor & gi|10716563 & 67526 \\
\hline & $\mathrm{Y}$ & $\mathrm{Y}$ & tumor necrosis factor type 1 receptor associated protein TRAP-1 - human & gi|1082886 & 75295 \\
\hline & - & $\mathrm{Y}$ & unnamed protein product (=heat shock protein HSP 90-alpha) & gi|32488 & 85020 \\
\hline & - & $\mathrm{Y}$ & probable Xaa-Pro aminopeptidase 3 isoform 1 & gi|11559925 & 57034 \\
\hline & - & $\mathrm{Y}$ & importin subunit beta-1 isoform 1 & gi $\mid 19923142$ & 97108 \\
\hline \multirow[t]{5}{*}{8} & $\mathrm{Y}$ & $\mathrm{Y}$ & GRP78 precursor, partial & gi|386758 & 72071 \\
\hline & $\mathrm{Y}$ & - & protein disulfide-isomerase A4 precursor & gi| 4758304 & 72887 \\
\hline & $\mathrm{Y}$ & - & chain A, ATPase domain of human heat shock $70 \mathrm{kDa}$ protein 1 & gi $\mid 6729803$ & 41973 \\
\hline & $\mathrm{Y}$ & - & heat shock $70 \mathrm{kDa}$ protein 8 isoform 1 variant & gi|62897129 & 71083 \\
\hline & - & $\mathrm{Y}$ & moesin & gi $\mid 4505257$ & 67778 \\
\hline \multirow[t]{8}{*}{9} & $\mathrm{Y}$ & $\mathrm{Y}$ & heat shock cognate $71 \mathrm{kDa}$ protein isoform 1 & gi|5729877 & 70854 \\
\hline & $\mathrm{Y}$ & $\mathrm{Y}$ & heat shock $70 \mathrm{kDa}$ protein 9 (mortalin) & gi|12653415 & 73682 \\
\hline & Y & $\mathrm{Y}$ & heat shock $70 \mathrm{kDa}$ protein 6 & gi|34419635 & 70984 \\
\hline & $\mathrm{Y}$ & $\mathrm{Y}$ & HSP70-2 & gi|4529892 & 69982 \\
\hline & $\mathrm{Y}$ & - & chain A, crystal structure of a heat shock $70 \mathrm{kDa}$ protein 2 & gi|395759492 & 42130 \\
\hline & - & $\mathrm{Y}$ & unnamed protein product & gi| 194384180 & 54987 \\
\hline & - & $\mathrm{Y}$ & calelectrin & gi|179976 & 75857 \\
\hline & - & $\mathrm{Y}$ & $\mathrm{X}$-ray repair cross-complementing protein 6 isoform 1 & gi| 4503841 & 69799 \\
\hline \multirow[t]{7}{*}{10} & Y & $\mathrm{Y}$ & serum albumin & gi|28592 & 71316 \\
\hline & $\mathrm{Y}$ & - & unnamed protein product & gi| $\mid 194388088$ & 63885 \\
\hline & Y & - & similar to heat shock $70 \mathrm{kDa}$ protein 8 isoform 2 ; heat shock cognate protein & gi|51095054 & 13379 \\
\hline & Y & - & growth regulated nuclear 68 protein & gi|226021 & 66881 \\
\hline & $\mathrm{Y}$ & - & transketolase & gi|37267 & 67751 \\
\hline & $\mathrm{Y}$ & - & $\begin{array}{l}\text { dolichyl-diphosphooligosaccharide-protein glycosyltransferase subunit } \\
1 \text { precursor }\end{array}$ & gi| $\mid 4506675$ & 68527 \\
\hline & - & $\mathrm{Y}$ & lamin A protein, partial & gi|386856 & 57686 \\
\hline
\end{tabular}


Table 1. (continued)

\begin{tabular}{|c|c|c|c|c|c|}
\hline \multirow[t]{5}{*}{11} & $\mathrm{Y}$ & $\mathrm{Y}$ & $60 \mathrm{kDa}$ heat shock protein, mitochondrial & gi|31542947 & 61016 \\
\hline & $\mathrm{Y}$ & $\mathrm{Y}$ & pyruvate kinase & gi|35505 & 57841 \\
\hline & $\mathrm{Y}$ & $\mathrm{Y}$ & transformation upregulated nuclear protein & gi| $\mid 460789$ & 51040 \\
\hline & $\mathrm{Y}$ & - & keratin 1 & See band 5 & \\
\hline & $\mathrm{Y}$ & - & thyroid hormone binding protein precursor & gi|339647 & 57069 \\
\hline \multirow[t]{6}{*}{12} & $\mathrm{Y}$ & $\mathrm{Y}$ & calreticulin=calcium binding protein & gi|913148 & 3737 \\
\hline & $\mathrm{Y}$ & - & glucose-6-phosphate dehydrogenase & gi|26224790 & 54789 \\
\hline & $\mathrm{Y}$ & - & UDP-glucose 6-dehydrogenase isoform 1 & gi|4507813 & 54989 \\
\hline & $\mathrm{Y}$ & - & peptidyl-prolyl cis-trans isomerase FKBP4 & gi|4503729 & 51772 \\
\hline & - & $\mathrm{Y}$ & vimentin & gi|340219 & 53681 \\
\hline & - & $\mathrm{Y}$ & calreticulin precursor & gi| 4757900 & 48112 \\
\hline \multirow[t]{7}{*}{13} & $\mathrm{Y}$ & $\mathrm{Y}$ & tubulin alpha-1B chain & gi|34740335 & 50120 \\
\hline & $\mathrm{Y}$ & $\mathrm{Y}$ & tubulin beta- $4 \mathrm{~B}$ chain & gi|5174735 & 49799 \\
\hline & $\mathrm{Y}$ & $\mathrm{Y}$ & tubulin beta- 5 chain & gi|7106439 & 49639 \\
\hline & $\mathrm{Y}$ & - & cytokeratin 8 & gi|181573 & 53529 \\
\hline & $\mathrm{Y}$ & - & ATP synthase subunit beta, mitochondrial precursor & gi|32189394 & 56525 \\
\hline & - & Y & beta-tubulin & gi|338695 & 49727 \\
\hline & - & $\mathrm{Y}$ & alpha-tubulin & gi|37492 & 50810 \\
\hline \multirow[t]{5}{*}{14} & $\mathrm{Y}$ & $\mathrm{Y}$ & alpha-enolase isoform 1 & gi|4503571 & 47139 \\
\hline & $\mathrm{Y}$ & Y & elongation factor 1-gamma & gi|4503481 & 50087 \\
\hline & $\mathrm{Y}$ & - & cytokeratin $18(424 \mathrm{AA})$ & gi|30311 & 47305 \\
\hline & $\mathrm{Y}$ & - & cytokeratin 8 & See band 13 & \\
\hline & $\mathrm{Y}$ & - & protein kinase PKN beta & gi|6088096 & 99421 \\
\hline \multirow[t]{5}{*}{15} & $\mathrm{Y}$ & $\mathrm{Y}$ & phosphoglycerate kinase 1 & gi|4505763 & 44586 \\
\hline & $\mathrm{Y}$ & - & glial fibrillary acidic protein isoform 1 & gi|4503979 & 49850 \\
\hline & $\mathrm{Y}$ & - & keratin, type I cytoskeletal 19 & gi|24234699 & 44079 \\
\hline & - & $\mathrm{Y}$ & eukaryotic initiation factor 4AII & gi $\mid 485388$ & 46365 \\
\hline & - & $\mathrm{Y}$ & elongation factor $\mathrm{Tu}$ & gi|704416 & 49509 \\
\hline \multirow[t]{4}{*}{16} & $\mathrm{Y}$ & $\mathrm{Y}$ & actin, cytoplasmic 1 & gi|4501885 & 41710 \\
\hline & $\mathrm{Y}$ & $\mathrm{Y}$ & actin, alpha skeletal muscle & gi|4501881 & 42024 \\
\hline & $\mathrm{Y}$ & $\mathrm{Y}$ & beta-actin-like protein 2 & gi|63055057 & 41976 \\
\hline & $\mathrm{Y}$ & - & $40 \mathrm{kDa}$ keratin protein, partial & gi|386803 & 44065 \\
\hline \multirow[t]{6}{*}{17} & $\mathrm{Y}$ & $\mathrm{Y}$ & aldolase $\mathrm{A}$ & gi|28614 & 39307 \\
\hline & $\mathrm{Y}$ & - & actin prepeptide, partial & gi|178067 & 36783 \\
\hline & $\mathrm{Y}$ & - & cytokeratin $8(279 \mathrm{AA})$ & gi|30313 & 30840 \\
\hline & $\mathrm{Y}$ & - & 40 S ribosomal protein $\mathrm{S} 24$ isoform C & gi|4506703 & 15413 \\
\hline & - & $\mathrm{Y}$ & $40 \mathrm{~S}$ ribosomal protein $\mathrm{SA}$ & gi|9845502 & 32833 \\
\hline & - & $\mathrm{Y}$ & laminin-binding protein,partial & gi|34234 & 32854 \\
\hline \multirow[t]{6}{*}{18} & $\mathrm{Y}$ & $\mathrm{Y}$ & glyceraldehyde-3-phosphate dehydrogenase & gi|31645 & 36031 \\
\hline & Y & $\mathrm{Y}$ & $\begin{array}{l}\text { chain R, twinning in crystals of human skeletal muscle D-glyceraldehyde-3- } \\
\text { phosphate dehydrogenase }\end{array}$ & gi|230867 & 35853 \\
\hline & $\mathrm{Y}$ & - & myotubularin-related protein 14 isoform 2 & gi|117938270 & 72158 \\
\hline & $\mathrm{Y}$ & - & $40 \mathrm{kDa}$ keratin protein, partial & gi|34039 & 44079 \\
\hline & $\mathrm{Y}$ & - & keratin 1 & See band 5 & \\
\hline & - & Y & annexin A1 & gi|4502101 & 38690 \\
\hline \multirow[t]{3}{*}{19} & $\mathrm{Y}$ & $\mathrm{Y}$ & ribosomal protein L6 & gi|36138 & 32841 \\
\hline & $\mathrm{Y}$ & - & fructose-1,6-bisphosphatase & gi|182311 & 36805 \\
\hline & - & $\mathrm{Y}$ & annexin A2 & gi| $\mid 18645167$ & 38552 \\
\hline 20 & - & $\mathrm{Y}$ & chain $\mathrm{A}$, the effect of metal binding on the structure of annexin & gi|809185 & 35783 \\
\hline
\end{tabular}

$\mathrm{Y}$, line consisting of the protein. 
their cognate nuclear receptors (Beato and Klug 2000) and in the response to stress (Beere 2004). Within 32 proteins detected only in estrogen receptor-positive MCF-7 cells, fatty acid synthase expression and activity have been shown to be mediated by the $\mathrm{G}$ protein-coupled estrogen receptor in cancer cells and cancer-associated fibroblasts that strongly contribute to cancer progression (Santolla et al. 2012). Also, the relationships among estrogen receptor, progesterone receptor and glucose-6-phosphate dehydrogenase activity have been demonstrated in MCF-7 cells (Nerurkar et al. 1990). Within 30 proteins detected in estrogen receptor-negative MDA-MB-231 cells, moesin plays a marked role in the cancer cell invasiveness and pattern of metastasis characteristic of estrogen receptor-negative breast cancers (Carmeci et al. 1998). All-trans retinoic acid acting through nuclear retinoid receptors was found to increase the expression of all-trans retinoic acid receptor beta causing an inhibition of the $60 \%$ in cell migration and significantly decreases the expression of moesin and other migration-related proteins (Flamini et al. 2014).

Among proteins with regard to early cancer detection, of importance are predominantly heat shock protein HSP 90 -beta isoform a (band 7), or heat shock $70 \mathrm{kDa}$ protein 8 isoform 1 (band 8).

As expected, some well-known human breast cancer markers, such as annexins were also identified in this experiment. According to our results, annexin A1 and A2 (band 18 and 19) are selectively expressed in the invasive/ metastatic MDA-MB-231 cells but not in the invasive/ nonmetastatic MCF-7. Generally, annexins are proteins capable to reversibly bind to negatively charged phospholipids in a $\mathrm{Ca}^{2+}$-mediated manner (Moss and Morgan 2004; Laohavisit and Davies 2009; Peng et al. 2014). Annexin A1 seems to act as a tumour suppressor in cells. Strong downregulation of annexin A1 has been described at prostate, head, neck, and esophageal cancers, and on the other hand, up-regulation at hepatocarcinoma and pancreatic cancer (Ang et al. 2009). Increased expression of annexin A2 is also frequently observed in a broad spectrum of cancer cells (Wang and Lin 2014).

In contrast, only MCF-7 cells were found to be positive for cytokeratins and keratins (band 5, 11, 13, 14, 15, 16, 18). This finding is in a good agreement with results of Whelan et al. (2012) who described keratin 8 and 18 as other potential biomarkers in conjunction with keratin 19.

In the group marked as "others", we have found a lot of differently expressed proteins. The protein (band 12), which was identified from the spot about $50 \mathrm{kDa}$, represents an example of noticeable differences in the electrophoretic profiles of both cell lines. It corresponds to vimentin, specific protein for MDA-MB-231, which has been known to participate in a number of crucial functions, often related to organization of proteins that are involved in adhesion, migration, and cell signaling (Ivaska et al. 2007). Expression of this mesenchymal marker only in MDA-MB-231 cells and its non-detectability in the MCF-7 cells have also been described by other authors (Blick et al. 2008).

In conclusion, using basic proteomic analysis, we compared two different human breast cancer cell lines - MCF-7 and MDA-MB-231. Our attention was focused predominantly on major differences in their protein pattern, since, the differences in their phenotypes, especially from the protein composition point of view, have not been taken into account by many scientists (Mladkova et al. 2010). MALDI-TOF MS revealed almost one hundred proteins and 30 of them seem to be either up-regulated or specific to MDA-MB-231 in comparison with MCF-7 cells.

Thus, we presented the usefulness of this approach that can be utilized for basic comparisons of protein patterns of selected or unknown and new cell lines. Additionally, in this way, it is possible to specify a set of proteins recorded only in the particular lines, as we have shown in this work. Subsequently a decision about usage of the cells can be made based on their above mentioned proteomic similarity or dissimilarity.

Acknowledgements. This work was supported by APVV-016011, VEGA 2/0171/14, institutional support RVO:68081715 of the Institute of Analytical Chemistry of the CAS, v. v. i., SAV-15-01 and SAV-AVCR-15-01 grants.

\section{References}

Ang E. Z., Nguyen H. T., Sim H. L., Putti T. C., Lim L. H. (2009): Annexin-1 regulates growth arrest induced by high levels of estrogen in MCF-7 breast cancer cells. Mol. Cancer Res. 7, 266-274 http://dx.doi.org/10.1158/1541-7786.MCR-08-0147

Beato M., Klug J. (2000): Steroid hormone receptors: an update. Hum. Reprod. Update 6, 225-236 http://dx.doi.org/10.1093/humupd/6.3.225

Beere H. M. (2004): „The stress of dying“: the role of heat shock proteins in the regulation of apoptosis. J. Cell Sci. 117, 2641-2651 http://dx.doi.org/10.1242/jcs.01284

Bialesova L., Novotna A., Macejova D., Brtko J., Dvorak Z. (2015): Agonistic effect of selected isoflavones on arylhydrocarbon receptor in a novel AZ-AhR transgenic gene reporter human cell line. Gen. Physiol. Biophys. 34, 331-334 http://dx.doi.org/10.4149/gpb_2015008

Blick T., Widodo E., Hugo H., Waltham M., Lenburg M. E., Neve R. M., Thompson E. W. (2008): Epithelial mesenchymal transition traits in human breast cancer cell lines. Clin. Exp. Metastasis 25, 629-642 http://dx.doi.org/10.1007/s10585-008-9170-6

Cailleau R., Young R., Olive M., Reeves W. J. Jr. (1974): Breast tumor cell lines from pleural effusions. J. Natl. Cancer Inst. $53,661-674$ 
Carmeci C., Thompson D. A., Kuang W. W., Lightdale N., Furthmayr H., Weigel R. J. (1998): Moesin expression is associated with the estrogen receptor-negative breast cancer phenotype. Surgery 124, 211-217 http://dx.doi.org/10.1016/S0039-6060(98)70122-9

Farinha A. P., Irar S., de Oliveira E., Oliveira M. M., Pages M. (2011): Novel clues on abiotic stress tolerance emerge from embryo proteome analyses of rice varieties with contrasting stress adaptation. Proteomics 11, 2389-2405 http://dx.doi.org/10.1002/pmic.201000570

Flamini M. I., Gauna G. V., Sottile M. L., Nadin B. S., Sanchez A. M., Vargas-Roig L. M. (2014): Retinoic acid reduces migration of human breast cancer cells: role of retinoic acid receptor beta. J. Cell Mol. Med. 18, 1113-1123 http://dx.doi.org/10.1111/jcmm.12256

Ivaska J., Pallati H-M., Nevo J., Eriksson J. E. (2007): Novel functions of vimentin in cell adhesion, migration, and signaling. Exp. Cell Res. 313, 2050-2062 http://dx.doi.org/10.1016/j.yexcr.2007.03.040

Keen J. C. (2011): Breast cancer cell line development and authentication. In: Breast Cancer - Focusing Tumor Microenvironment, Stem cells and Metastasis. (Eds. M. Gunduz and E. Gunduz), pp. 3-20, InTech Europe, Rijeka

Khan N. J. (2013): Cell lines: an in vitro model to study breast cancer. International Journal for Innovative Research in Science and Technology 2, 7214-7219

Laohavisit A., Davies J. M. (2009): Multifunctional annexins. Plant Sci. 177, 532-539 http://dx.doi.org/10.1016/j.plantsci.2009.09.008

Levenson A. S, Jordan V. C. (1997): MCF-7: the first hormoneresponsive breast cancer cell line. Cancer Res. 57, 3071-3078

Mladkova J., Sanda M., Matouskova E., Selicharova I. (2010): Phenotyping breast cancer cell lines EM-G3, HCC1937, MCF7 and MDA-MB-231 using 2-D electrophoresis and affinity chromatography for glutathione-binding proteins. BMC Cancer 10, 449 http://dx.doi.org/10.1186/1471-2407-10-449

Moss S. E., Morgan R. O. (2004): The annexins. Genome Biol. 5, 219

http://dx.doi.org/10.1186/gb-2004-5-4-219

Nerurkar V. R., Ishwad C. S., Seshadri R., Naik S. N., Lalitha V. S. (1990): Glucose-6-phosphate dehydrogenase and 6-phosphogluconate dehydrogenase activities in normal canine mammary gland and in mammary tumours and their correlation with oestrogen receptors. J. Comp. Pathol. 102, 191-195 http://dx.doi.org/10.1016/S0021-9975(08)80124-7

Peng B., Guo C., Guan H., Liu S., Sun M. Z. (2014): Annexin A5 as a potential marker in tumors. Clin. Chim. Acta 427, 42-48 http://dx.doi.org/10.1016/j.cca.2013.09.048

Santolla M. F., Lappano R., De Marco P., Pupo M., Vivacqua A., Sisci D., Abonante S., Iacopetta D., Cappello A. R., Dolce V., Maggiolini M. (2012): G protein-coupled estrogen receptor mediates the up-regulation of fatty acid synthase induced by $17 \beta$-estradiol in cancer cells and cancer-associated fibroblasts. J. Biol. Chem. 287, 43234-43245 http://dx.doi.org/10.1074/jbc.M112.417303

Soule H. D., Vasquez J., Long A., Albert S., Brennan M. (1973): Human cell line from a pleural effusion derived from a breast carcinoma J. Natl. Cancer Inst. 51, 1409-1413

Wang C. Y., Lin C. F. (2014): Annexin A2: its molecular regulation and cellular expression in cancer development. Dis. Markers 2014, $1-10$ http://dx.doi.org/10.1155/2014/308976

Whelan S. A., He J. B., Lu M., Souda P., Saxton R. E., Faull K. F., Whitelegge J. P., Chang H. R. (2012): Mass Spectrometry (LCMS/MS) identified proteomic biosignatures of breast cancer in proximal fluid. J. Proteome Res. 11, 5034-5045 http://dx.doi.org/10.1021/pr300606e

Received: February 18, 2016

Final version accepted: February 26, 2016

First published online: May 13, 2016 